\title{
KARAKTERISTIK FLAKES YANG DIHASILKAN DARI TEPUNG HANJELI (Coix lacryma jobi L.) TERMODIFIKASI DENGAN METODE HEAT MOISTURE TREATMENT
}

\author{
Hervelly, Yudi Garnida, Ajeng Galih Nastiti
}

\author{
Program Studi Teknologi Pangan, Fakultas Teknik, Universitas Pasundan, Jl. Dr.Setiabudi No 93, Bandung, 40153, \\ Indonesia \\ E-mail : hervelly@unpas.ac.id
}

Diterima pertama kali: 12 Januari 2020, Direvisi: 13 Januari 2020, Disetujui untuk publikasi: 16 Januari 2020

\begin{abstract}
The aim of this study was obtained suitable conditions on the modification of hanjeli flour with variations of hanjeli flour moisture and heating temperature so as to improve the characteristics of hanjeli flour and increased its used into flakes products. The benefit of this study was an increase the added value of local raw materials that widely used, to utilized the technology of modification method of Heat Moisture Treatment for food processing made from raw hanjeli for hanjeli characteristics can be applied to flakes products. The study was divided into three stages: preliminary, main and second research. The experimental design used in this study was Randomized Block Design (RBD) consist of two factors: moisture level and heating temperature with 3 levels and 3 time replications, so that 27 experimental units were obtained. The treatment design consisted of variations was conducted in moisture a1 (20\%), a2 (25\%), a3 (30\%), and heating temperature $\mathrm{b} 1(90 \mathrm{oC}), \mathrm{b} 2(100 \mathrm{oC}), \mathrm{b} 3(110 \mathrm{oC})$. The result of this study was obtained that the selected sample were a3b1 (moisture level 30\% and heating temperature 90oC) with an average water content 9,657\%, amylose 8,393\% and setback viscosity $955,000 \mathrm{cP}$. The preparation of flakes from selected modified hanjeli flour was tested for water content, amylose, water absorption of flakes and the organoleptic response
\end{abstract}

Keyword:Hanjeli, flour, Moisture.

\section{Pendahuluan}

Masyarakat urban cenderung menerapkan pola makan yang serba instan, praktis dan siap saji. Nurjanah (2000), menyatakan olahan sereal yang banyak dikonsumsi selain mie dan roti, yaitu produk sereal, seperti minuman sarapan, produk ekstrusi dan flakes menempati angka tertinggi pola konsumsi masyarakat. Flakes adalah makanan yang dibuat dari biji-bijian dan diolah menjadi adonan berbentuk lembaran atau kepingan tipis yang dapat dikonsumsi dengan penambahan susu atau flakes dapat dimakan langsung sebagai kudapan (Tarmizi, 2015).

Sereal flakes yang beredar dipasaran sebagian besar dibuat dari campuran tepung terigu. Tepung terigu berasal dari gandum yang tidak cocok ditanam di Indonesia sehingga untuk memperoleh bahan baku tepung terigu ini masih harus melakukan impor dari negara lain. Berdasarkan hal tersebut upaya yang dapat dilakukan adalah mengurangi produk berbahan dasar terigu dengan mengembangkan produk berbasis sumber pangan lokal yang mampu menjadi pensubtitusi tepung terigu atau mengantikan tepung terigu secara utuh.

Hanjeli memiliki potensi yang besar untuk dikembangkan menjadi pangan alternatif non-terigu. Hanjeli memiliki kandungan karbohidrat sebesar 76,4\%, protein $14,1 \%$, lemak $7,9 \%$, vitamin B1 0,48 mg, kalsium $54 \mathrm{mg}$ dan serat $0,9 \%$. Selain itu, kandungan protein, lemak dan vitamin $\mathrm{B}_{1}$ hanjeli lebih tinggi bila dibandingkan dengan beras, jagung, millet dan sorgum
(Grubben dan Partohardjono, 1996 dalam Munawar, 2016).

Pati alami yang terdapat pada biji hanjeli mempunyai beberapa kekurangan yaitu membutuhkan waktu yang lama dalam pengolahan, pasta yang terbentuk lengket dan tidak tahan terhadap perlakuan dengan asam (Nurmala, 2011). Untuk memperbaiki karakteristik tepung hanjeli dapat dilakukan modifikasi sifat pati alami hanjeli. Metode modifikasi yang paling efisien adalah modifikasi secara fisik. Modifikasi pati menggunakan metode fisik memiliki kelebihan cenderung lebih aman serta lebih alami dibanding dengan perlakuan kimia (Putri dan Elok, 2017). Metode ini relatif murah dan aman sebab tidak menggunakan bahan kimia sehingga tidak meninggalkan residu (Siwi dan Widya, 2013).

Heat Moisture Treatment (HMT) merupakan modifikasi pati secara fisik terhadap granula pati dengan kadar air kurang dari 35\% (kondisi lembab) selama 15 menit sampai dengan 16 jam, pada suhu $80^{\circ} \mathrm{C}$ sampai dengan $120^{\circ} \mathrm{C}$ (Pangesti dkk., 2014). HMT menyebabkan perubahan karakteristik fisikokimia tepung, perubahan yang terjadi meliputi morfologi granula, kristalinitas pati dan karakteristik gelatinisasi. Perubahan dipengaruhi oleh kondisi proses (kadar air, suhu dan waktu) serta kondisi pati (jenis pati, kadar amilosa pati dan kadar amilopektin pati). Berdasarkan hal tersebut, interaksi antara kondisi proses penting dipahami untuk menghasilkan tepung HMT dengan karakteristik yang konsisten untuk diaplikasikan ke 
dalam produk pangan (Syamsir dkk., 2012). Penelitian ini menentukan perlakuan HMT dengan faktor variasi kadar air yang dapat menyebabkan reformasi struktur amilosa dan amilopektin, sehingga granula pati lebih mudah menyerap air (Santosa dkk., 2018). Faktor kedua adalah variasi suhu pemanasan, dimana semakin tinggi suhu dapat menurunkan kelarutan pati (Sunyoto dkk., 2016).

\section{Metode Penelitian}

Bahan-bahan yang digunakan pada penelitian adalah biji hanjeli varietas Pulut (Hanjeli Ketan) sebanyak $2 \mathrm{~kg}$ yang telah disosoh atau berupa beras hanjeli diperoleh dari Kelompok Wanita Tani (KWT) "Pantastik" di Desa Sukajadi, Wado, Kabupaten Sumedang, tepung terigu (Kunci Biru), gula halus (Anggur), garam (Cap Kapal), dan air.

Bahan-bahan kimia untuk analisis yang digunakan pada penelitian yaitu alkohol 95\%, $\mathrm{NaOH} 1$ $\mathrm{N}, \mathrm{I}_{2}$, asam asetat $0,5 \mathrm{~N}$, potato amylosa, alkohol $90 \%$, dan aquadest.

Alat-alat yang digunakan dalam penelitian ini adalah loyang ceper, alumunium foil, tray, tunnel drier, ayakan 80 mesh, neraca digital, botol semprot, refrigator, roaster kopi, oven, mesin penggiling tepung, baskom, pisau, alat pencetak mie (Atlas).

Alat-alat yang digunakan untuk analisis adalah cawan, tang krus, desikator, oven analitik (Memmert), neraca analitik, gelas kimia (pyrex), penjepit kayu, spatula, labu ukur (pyrex), tabung reaksi (Pyrex), pipet berukuran, waterbath, spektrofotometer, sentrifugator, tabung sentrifuge (Pyrex)), petri disk, alat Ravid Visco Analyzer (RVA) DV-II Pro, corong (Pyrex), batang pengaduk.

Penelitian yang dilakukan dibagi dalam 3 tahap yaitu penelitian pendahuluan, penelitian utama dan penelitian utama lanjutan.

Penelitian pendahuluan yang dilakukan yaitu pembuatan tepung hanjeli alami metode kering kemudian dilakukan analisis kadar air metode gravimetri (AOAC, 2005), kadar amilosa (SNI 61282008) dan sifat amilografi (Brookfield Engineering).

Rancangan perlakuan terdiri dari dua faktor, yaitu kadar air (A) tepung hanjeli terdiri atas 3 taraf dan suhu pemanasan (B) terdiri atas 3 taraf, dengan urutan sebagai berikut:

Faktor kadar air modifikasi tepung hanjeli metode Heat Moisture Treatment (HMT) (A), terdiri dari 3 taraf, yaitu:

$a_{1}=20 \%, a_{2}=25 \%, a_{3}=30 \%$

Faktor suhu pemanasan modifikasi tepung hanjeli metode Heat Moisture Treatment (HMT) (B), terdiri dari 3 taraf yaitu:

$\mathrm{b}_{1}=90^{\circ} \mathrm{C}, \mathrm{b}_{2}=100^{\circ} \mathrm{C}, \mathrm{b}_{3}=110^{\circ} \mathrm{C}$

Model rancangan percobaan yang digunakan pada penelitian utama ini adalah pola faktorial $(3 \times 3)$ Rancangan Acak Kelompok (RAK) dengan 3 kali ulangan untuk setiap kombinasi perlakuan sehingga diperoleh 27 perlakuan.

Untuk membuktikan adanya perbedaan pengaruh perlakuan dan interaksinya terhadap semua respon variabel yang diamati, maka dilakukan analisis data dengan model percobaan sebagai berikut:

$$
Y i j k=\mu+\beta i+A j+B k+(A B) i j+\varepsilon i j k
$$

Dimana:

Yijk = hasil pengamatan dari kelompok ke-k yang memperoleh taraf ke-i dari faktor kadar air (A) dan taraf $\mathrm{j}$ dari faktor suhu pemanasan (B)

$\mu \quad=$ rata-rata umum yang sebenarnya

$\mathrm{Bi} \quad=$ pengaruh kelompok ulangan ke-i

$\mathrm{Aj} \quad=$ pengaruh dari faktor kadar air $(\mathrm{A})$ pada perlakuan ke-j

$\mathrm{Bk}=$ pengaruh faktor suhu pemanasan (B) pada perlakuan ke-k

$(\mathrm{AB}) \mathrm{ij}=$ pengaruh interaksi antara taraf ke-i faktor $\mathrm{A}$ dan taraf ke-j faktor B

eijk = pengaruh galat percobaan pada kelompok ke-i yang memperoleh taraf ke-j faktor A, dan taraf ke-k faktor $B$.

\section{Hasil dan Pembahasan \\ Hasil Penelitian Pendahuluan}

Penelitian pendahuluan yang dilakukan adalah pembuatan tepung hanjeli tanpa modifikasi, selanjutnya dilakukan analisis. Hasil analisis tepung hanjeli tanpa modifikasi adalah kandungan kadar air sebesar $10,400 \%$, kadar amilosa $9,810 \%$, suhu awal gelatinisasi 82,100 dan viskositas balik sebesar 80,000 cP.

\section{Hasil Penelitian Utama}

1. Kadar Air

Tepung hanjeli tanpa HMT menghasilkan kadar air sebesar $10,400 \%$, sedangkan kadar air tepung hanjeli HMT berkisar antara 7,377\%-9,657\%.

Berdasarkan hasil perhitungan ANAVA menunjukkan bahwa kadar air (A) dan suhu pemanasan (B) modifikasi tepung hanjeli dengan metode Heat Moisture Treatment (HMT) serta interaksinya (AB) berpengaruh terhadap kadar air tepung hanjeli modifikasi yang dihasilkan. Pengaruh interaksi kadar air dan suhu pemanasan modifikasi Heat Moisture Treatment (HMT) terhadap kadar air tepung modifikasi dapat dilihat pada Tabel 1.

Hasil penelitian menunjukkan rata-rata setiap perlakuan dengan semakin tinggi penambahan kadar air menyebabkan kenaikan kadar air. Hal ini diduga akibat penambahan kadar air menyebabkan peristiwa imbibisi pada bahan sehingga permukaan terluar bahan mampu menyerap air. Kemudian air terperangkap di dalam tepung hanjeli akibat berikatan dengan molekul amilosa selama molekul amilosa mengalami penyusunan ulang. Modifikasi menyebabkan kecenderungan saling berikatannya kembali molekul amilosa dengan amilosa 
pada pasta pati melalui ikatan hidrogen diantara gugus hidroksilnya menjadi kristal tidak larut.

Tabel 1. Pengaruh Interaksi Kadar Air dan Suhu Pemanasan Modifikasi Metode Heat Moisture Treatment (HMT) Terhadap Kadar Air Tepung Modifikasi (\%)

\begin{tabular}{|c|c|c|c|}
\hline \multirow{2}{*}{$\begin{array}{c}\text { Kadar air } \\
\text { Modifikasi } \\
\text { HMT (A) }\end{array}$} & \multicolumn{3}{|c|}{$\begin{array}{l}\text { Suhu Pemanasan Modifikasi HMT } \\
\text { (B) }\end{array}$} \\
\hline & $\mathrm{b}_{1}\left(90^{\circ} \mathrm{C}\right)$ & $\mathrm{b}_{2}\left(100^{\circ} \mathrm{C}\right)$ & $\mathrm{b}_{3}\left(110^{\circ} \mathrm{C}\right)$ \\
\hline$a_{1}(20 \%)$ & $a{ }^{A, 517}{ }^{\mathrm{A}}$ & ${ }^{7,397^{\mathrm{A}}}$ & $\begin{array}{l} \\
\\
a^{2,377}\end{array}$ \\
\hline $\mathrm{a}_{2}(25 \%)$ & $\begin{array}{l}\text { B } \\
a^{2,040}\end{array}$ & $a^{8,016^{\mathrm{B}}}$ & $\begin{array}{l}\text { B } \\
\\
a^{2,897}\end{array}$ \\
\hline $\mathrm{a}_{3}(30 \%)$ & $b^{9,657^{C}}$ & ${ }{ } \mathrm{C}, 477^{\mathrm{C}}$ & $\begin{array}{l}\text { B } \\
\text { a } 8,260^{2}\end{array}$ \\
\hline
\end{tabular}

Keterangan: Huruf kecil dibaca arah horizontal dan huruf besar dibaca vertikal, huruf yang berbeda menyatakan perbedaan yang nyata pada taraf $5 \%$ pada uji lanjut Duncan.

2. Kadar Amilosa

Tepung hanjeli tanpa HMT menghasilkan kadar amilosa sebesar 9,810\%, sedangkan kadar amilosa tepung hanjeli HMT berkisar antara 8,393\%-9750\%.

Berdasarkan hasil perhitungan ANAVA menunjukkan kadar air (A), suhu pemanasan (B) modifikasi metode Heat Moisture Treatment (HMT) serta interaksinya $(\mathrm{AB})$ berpengaruh terhadap kadar amilosa tepung modifikasi yang dihasilkan. Pengaruh interaksi kadar air dan suhu pemanasan modifikasi metode Heat Moisture Treatment (HMT) terhadap kadar amilosa tepung modifikasi dapat dilihat pada Tabel 1 .

Tabel 1. Pengaruh Interaksi Kadar air dan Suhu Pemanasan Modifikasi Metode Heat Moisture Treatment (HMT) Terhadap Kadar Amilosa Tepung Modifikasi (\%)

\begin{tabular}{|c|c|c|c|}
\hline \multirow{2}{*}{$\begin{array}{c}\text { Kadar air } \\
\text { Modifikasi } \\
\text { HMT (A) }\end{array}$} & \multicolumn{3}{|c|}{$\begin{array}{l}\text { Suhu Pemanasan Modifikasi HMT } \\
\text { (B) }\end{array}$} \\
\hline & $\mathrm{b}_{1}\left(90^{\circ} \mathrm{C}\right)$ & $\mathrm{b}_{2}\left(100^{\circ} \mathrm{C}\right)$ & $\mathrm{b}_{3}\left(110^{\circ} \mathrm{C}\right)$ \\
\hline$a_{1}(20 \%)$ & $\begin{array}{l}\text { A } \\
\mathrm{a}^{2,517} \\
\end{array}$ & $\begin{array}{l}\mathrm{A} \\
\mathrm{a}^{7,397}\end{array}$ & $\begin{array}{ll} & \mathrm{A} \\
\mathrm{a} & \\
& \end{array}$ \\
\hline $\mathrm{a}_{2}(25 \%)$ & $\begin{array}{l}\text { B } \\
\mathrm{a}^{2} \\
\end{array}$ & $a^{8,016}$ & $\begin{array}{l}\text { B } \\
\\
\text { a } \\
\end{array}$ \\
\hline $\mathrm{a}_{3}(30 \%)$ & $b^{9,657^{C}}$ & ${ } \quad \begin{array}{l}\mathrm{C} \\
\mathrm{a}\end{array}$ & $\begin{array}{l}\text { B } \\
a 8,260^{2}\end{array}$ \\
\hline
\end{tabular}

Keterangan: Huruf kecil dibaca arah horizontal dan huruf besar dibaca vertikal, huruf yang berbeda menyatakan perbedaan yang nyata pada taraf $5 \%$ pada uji lanjut Duncan.
Hasil penelitian menunjukkan bahwa perubahan kadar amilosa yang terjadi antar perlakuan kadar air dan suhu pemanasan modifikasi HMT cenderung menurunkan kadar amilosa. Hal tersebut disebabkan oleh penambahan air akan berikatan dengan amilosa, amilosa bersifat mudah larut dalam air sehingga amilosa keluar dari granula selama pemanasan dengan air berlebih. Peluruhan amilosa menandakan adanya transisi di dalam granula pati dari teratur menjadi tidak teratur ketika pati dipanaskan dengan air berlebih.

3. Suhu Awal Gelatinisasi

Tepung hanjeli tanpa HMT memiliki suhu awal gelatinisasi $81,2 \mathrm{cp}$, sedangkan suhu awal gelatinisasi tepung hanjeli HMT berkisar antara $74,7^{\circ} \mathrm{C}-79,7^{\circ} \mathrm{C}$.

Berdasarkan hasil perhitungan ANAVA menunjukkan kadar air (A) modifikasi tepung hanjeli tidak berpengaruh terhadap suhu awal gelatinisasi, namun suhu pemanasan (B) modifikasi tepung hanjeli metode Heat Moisture Treatment (HMT berpengaruh terhadap suhu awal gelatinisasi tepung modifikasi yang dihasilkan dan tidak ada interaksi (AB) kedua faktor.

Hasil penelitian menunjukkan bahwa semakin tinggi suhu pemanasan modifikasi pati metode HMT cenderung menyebabkan kenaikan suhu awal gelatinisasi. Perbedaan suhu awal gelatinisasi dapat disebabkan oleh adanya pembentukan ikatan antara amilosa-amilosa, amilosa-amilopektin dan amilopektinamilopektin yang dihasilkan pada saat proses modifikasi sehingga membutuhkan suhu yang lebih tinggi agar granula pati dapat menyerap air dan terjadi peningkatan viskositas. Hal ini disebabkan oleh proses rekristalisasi komponen granula pati terjadi interaksi molekular pada daerah kristalin dan amorf yang membentuk struktur kuat dengan ikatan hidrogen, sehingga mendorong interaksi antara rantai polimer amilosa dan amilopektin pada struktur granula semakin menghasilkan struktur yang lebih kompak.

\section{Viskositas Balik}

Tepung hanjeli tanpa HMT menghasilkan viskositas balik sebesar $80 \mathrm{cP}$, sedangkan tepung hanjeli HMT memiliki viskositas balik yang berkisar antara $235,000 \mathrm{cP}-955,000 \mathrm{cP}$.

Berdasarkan hasil perhitungan ANAVA menunjukkan kadar air (A) dan suhu pemanasan (B) modifikasi metode Heat Moisture Treatment (HMT) serta interaksi keduanya (AB) berpengaruh terhadap viskositas balik tepung modifikasi yang dihasilkan. Pengaruh interaksi kadar air dan suhu pemanasan modifikasi metode Heat Moisture Treatment (HMT) terhadap viskositas balik tepung modifikasi metode Heat Moisture Treatment (HMT) dapat dilihat pada Tabel 3.

Hasil penelitian menunjukkan bahwa viskositas balik pasca HMT dengan kombinasi pengaruh kadar air dan suhu pemanasan memberikan nilai yang fluktuatif namun cenderung meningkat. Hal ini diakibatkan perlakuan HMT dapat meningkatkan ikatan silang di antara pati terutama pada fraksi amilosa sehingga 
meningkatkan viskositas balik. Viskositas balik dipengaruhi oleh jumlah amilosa yang terlepas, ukuran granula, rigiditas dan granula mengembang yang tidak terfragmentasi (Zavareze, dkk., 2010).

Tabel 3. Pengaruh Interaksi Kadar air dan Suhu Pemanasan Modifikasi Metode Heat Moisture Treatment (HMT) Terhadap Viskositas Balik Tepung Modifikasi (cP)

\begin{tabular}{|c|c|c|c|}
\hline \multirow{2}{*}{$\begin{array}{l}\text { Kadar air } \\
\text { Modifikasi } \\
\text { HMT (A) }\end{array}$} & \multicolumn{3}{|c|}{$\begin{array}{l}\text { Suhu Pemanasan Modifikasi HMT } \\
\text { (B) }\end{array}$} \\
\hline & $b_{1}\left(90^{\circ} \mathrm{C}\right)$ & $\mathrm{b}_{2}\left(100^{\circ} \mathrm{C}\right)$ & $\mathrm{b}_{3}\left(110^{\circ} \mathrm{C}\right)$ \\
\hline$a_{1}(2$ & $\begin{array}{l}\text { A } \\
\mathrm{b}^{483,333} \\
\end{array}$ & $\begin{array}{l}{ }^{2} \\
c^{5} \\
\end{array}$ & $\begin{array}{l}\text { A } \\
235,000 \\
a^{2}\end{array}$ \\
\hline$a_{2}(25 \%)$ & $\begin{array}{l}\mathrm{A} \\
508,333 \\
\mathrm{~b}\end{array}$ & $\begin{array}{l}\text { A } \\
270,000 \\
\mathrm{a}^{2}\end{array}$ & $\begin{array}{l}\text { B } \\
525,000\end{array}$ \\
\hline $\mathrm{a}_{3}(30 \%)$ & $\begin{array}{l}\text { B } \\
\text { c }\end{array}$ & ${ }^{323,333}{ }^{\text {B }}$ & ${ }_{b} 790,000$ \\
\hline
\end{tabular}

Keterangan: Huruf kecil dibaca arah horizontal dan huruf besar dibaca vertikal, huruf yang berbeda menyatakan perbedaan yang nyata pada taraf $5 \%$ pada uji lanjut Duncan.

\section{Penentuan Sampel Terpilih}

Hasil analisis uji kadar air, kadar amilosa dan sifat amilografi pada penelitian utama telah diuji, sampel terpilih didapat dari hasil pengujian sifat amilografi (viskositas balik) yang diinginkan pada produk flakes. Berdasarkan hasil analisis terhadap respon sifat amilografi didapatkan sampel terpilih yaitu sampel $a_{3} b_{1}$ (perlakuan kadar air $30 \%$ dan suhu pemanasan $90^{\circ} \mathrm{C}$ ) dengan nilai viskositas balik tertinggi yaitu $955,000 \mathrm{cP}$.

\section{Penelitian Utama Lanjutan}

Penelitian utama lanjutan yang dilakukan adalah aplikasi tepung terpilih untuk dijadikan produk flakes. Berdasarkan hasil pengujian didapatkan kadar air flakes tepung hanjeli HMT memiliki kadar air 3,041\%, kadar amilosa $11,240 \%$, daya serap air flakes $59,924 \%$ dan hasil pengujian organoleptik flakes tepung hanjeli modifikasi HMT didapatkan hasil rata-rata nilai kesukaan panelis untuk atribut warna, kerenyahan dan rasa menunjukkan angka berturut-turut 4 (empat), 5 (lima) dan 4 (empat), hal ini berarti flakes tepung hanjeli modifikasi HMT disukai panelis dalam hal warna, kerenyahan dan rasa.

\section{Keismpulan} bahwa:

Berdasarkan hasil penelitian dapat disimpulkan

1. Faktor kadar air (A) berpengaruh terhadap kadar air, kadar amilosa dan viskositas balik, namun tidak berpengaruh terhadap suhu awal gelatinisasi.
2. Faktor suhu pemanasan (B) berpengaruh terhadap kadar air, kadar amilosa, suhu awal gelatinisasi dan viskositas balik.

3. Interaksi (AB) antara kadar air dan suhu pemanasan modifikasi berpengaruh terhadap kadar air, kadar amilosa, dan viskositas balik, namun tidak berpengaruh terhadap suhu awal gelatinisasi.

\section{Daftar Pustaka}

1. Budiyati, R. (2010). Formulasi Tepung Komposit Berbasis Pati Ganyong (Canna edulis Kerr.) Termodifikasi Heat Moisture Treatment dan Tepung Kacang Tunggak (Vigna unguculata) Pada Pembuatan Mi Kering. Skripsi. Fakultas Teknologi Pertanian. Institut Pertanian Bogor. Bogor.

2. Fitriani, S., Evi B., dan Rahmayuni. (2010). Karakteristik Mutu Pati Sagu dari Provinsi Riau dengan Perlakuan Heat Moisture Treatment. Program Studi Teknologi Hasil Pertanian. Fakultas Pertanian Universitas Riau.

3. Koswara, S. (2009). Teknologi Modifikasi Pati. Tersedia pada: ebookpangan.com. Diakses: $11 \mathrm{Mei}$ 2018.

4. Lorenz, K. dan Kulp, K. (1981). Heat-moisture treatment of starches II: Functional properties and baking potential. Di dalam: Manuel, H.J. (1996). The Effect of Heat-Moisture Treatment on The Structure and Physicochemical Properties of Legume Starches. Thesis. Department of Biochemistry. Memonal University of Newfoundland Canada.

5. Marta, H., Marsetio, Yana C., dan Arum G.P. (2016). Sifat Fungsional dan Amilografi Pati Millet Putih (Pennisetum glaucum)Termodifikasi secara Heat Moisture Treatment dan Annealing. Jurnal Aplikasi Teknologi Pangan 5 (3) hal 76-84.

6. Munawar, L.T. (2016). Pengaruh Konsentrasi Senyawa Phospat dan Perbandingan Air Perebusan Terhadap Karakteristik Tepung Instan Hanjeli (Coix lacryma-jobi L). Skripsi. Program Studi Teknologi Pangan. Fakultas Teknik Universitas Pasundan. Bandung.

7. Nurjanah, E. (2000). Analisis Karakteristik Konsumen dan Pola Konsumsi Sereal Sarapan. Skripsi. Institut Pertanian Bogor. Bogor.

8. Nurmala, T. (2011). Potensi dan Prospek Pengembangan Hanjeli (Coix lacrima joi L) sebagai Pangan Bergizi Kaya Lemak untuk Mendukung Diversifikasi Pangan Menuju Ketahanan Pangan Mandiri. Artikel Pangan Vol. 20 No. 1 Maret 2011 hal. 41-48.

9. Pangesti, Y.D., Nur H.R.P., dan Achmad R.A. (2014). Kajian Sifat Fisikokimia Tepung Bengkuang (Pachyrhizus erous) Dimodifikasi Secara Heat Moisture Treatment (HMT) Dengan Variasi Suhu. Jurnal Teknologi Pangan Vol 3 Juli 2014 hal. 72-77. 
10. Putra, I. N. K., Ni W. W., dan Anak A. I. S. W. (2015). Optimasi Suhu Pemanasan dan Kadar Air pada Produksi Pati Talas Kimpul Termodifikasi dengan Teknik Heat Moisture Treatment (HMT). Jurusan Ilmu dan Teknologi Pangan Fakultas Teknologi Pertanian. Universitas Udayana. Bali.

11. Putri, W.D.R., dan Elok Z. (2017). Pati: Modifikasi dan Karakteristiknya. Universitas Brawijaya. Malang.

12. Rahma, R.N. (2017). Modifikasi Tepung Ganyong (Canna edulis Kerr.) Metode Heat Moisture Treatment Pada Suhu Dan Waktu Pemanasan Berbeda Dan Aplikasi Tepung Pada Pembuatan Cookies. Skripsi. Universitas Pasundan. Bandung.

13. Santosa, H., Noer, A.H., Ahmad, D.F., dan Anwar, T. (2018). Pembuatan Beras Analog Berbahan Dasar Tepung Sukun Termodifikasi Heat Moisture Treatment. Departemen Teknik Kimia. Fakultas Teknik. Universitas Dipenogoro. Semarang.

14. Siwi, K.S., dan Widya D.R. (2013). Studi Perubahan Sifat Fisik Kimia Tepung Ubi Jalar Putih (Ipoema batatas Var. Sukuh) sebagai Efek Modifikasi Menggunakan Metode Heat Moisture Treatment. Universitas Brawijaya. Malang.

15. Sunyoto, M., R. Andoyo, H. Radiani A., dan Michelle C.T. (2016). Kajian Sifat Fungsional Pati Ubi Jalar melalui Perlakuan Modifikasi Heat Moisture Treatment Sebagai Sediaan Pangan Darurat. Jurnal Sains dan Teknologi Vol. 5, No. 2, Oktober 2016 hal. 846-854.

16. Syamsir, E., Purwayatno, H., Dedi F., Nuri A. dan Feri K. (2012). Pengaruh Proses Heat-Moisture Treatment (HMT) Terhadap Karakteristik Fisikokimia Pati. Departemen Ilmu dan Teknologi Pangan. Fakultas Teknologi Pertanian. Institut Pertanian Bogor. Bogor.

17. Syamsir, E. (2012). Sereal Sarapan. Terdapat pada: http://ilmupangan.blogspot.com/2012/02/serealsarapan.html. Diakses: 23 Mei 2018.

18. Tarmizi, M.R. (2015). Pengaruh Perbandingan Konsentrasi Tepung Sorgum Termodifikasi (Sorgum Bicolor $(l)$.) Dengan Tepung Terigu dan Suhu Pemanggangan Terhadap Sifat Fisiko Kimia Flakes Ikan Patin (Pangasius hypothalmus). Program Studi Teknologi Pangan. Fakultas Teknik. Universitas Pasundan. Bandung.

19.Zavareze, E.R., Storck, CR., Castro, L.A.S., Schirmer, M.A., and Dias, A.R.G. (2010). Effect of Heat-Moisture Treatment on Rice Starch of Varying Amylose Content. Food Chemistry. 121, 358-365.

20.Zhou, Y., Shaohua, M., Deyi, C., Xiping, Z., and Huaibo, Y. (2014). Structure Characterization And Hypoglycemic Effects of Dual Modified Resistant Starch From Indica Rice Starch. College of
Technology and Food Engineering. Hefei University of Technology. China. 